\title{
Ó TEMPOS! Ó SAUDADES! MACHADO DE ASSIS ESPECTADOR DE TEATRO
}

\author{
ALESSANDRA VANNUCCI \\ Universidade Federal do Rio de Janeiro \\ Rio de Janeiro, Rio de Janeiro, Brasil
}

Resumo: Machado de Assis foi espectador de teatro na corte do Segundo Reinado, registrando tal atividade na forma de crônicas, folhetins, pareceres para censura, contos e romances. Sua atuação como crítico contribuiu com a ampla campanha intelectual de formação de público, que o escritor abandonou em seguida, mostrando-se decepcionado com os rumos da desejada reforma da cena nacional. A partir de 1865, devotado à ficção, escreveu apenas ocasionalmente sobre teatro, abrindo exceção para cinco hiperbólicas resenhas por meio das quais acompanhou a primeira temporada brasileira (em 1869) da atriz italiana Adelaide Ristori, mundialmente consagrada como "rainha das cenas". Este ensaio procura inventariar as ideias teatrais de Machado e seus hábitos de espectador, cotejando as observações sobre o trabalho da atriz, até agora desconsideradas por especialistas da obra.

Palavras-chave: formação de público na Corte; Machado espectador de teatro; Adelaide Ristori.

\section{Ó TEMPOS! Ó SAUDADES! MACHADO DE ASSIS AS A THEATER SPECTATOR}

\begin{abstract}
Machado de Assis was a theater spectator in the Brazilian court of the Second Empire, a position he left a trail of in chronicles, serial novels, censorship reports, short stories and novels. His work as a critic was part of a broad intellectual campaign to cultivate theatre audiences, a mission he would later leave behind out of apparent disappointment over the path his desired reform of the national scene took. From 1865, devoted to fiction, he wrote only occasionally about theatre, making an exception for his hyperbolic reviews of the first Brazilian season (1869) of the Italian actress, Adelaide Ristori, internationally acclaimed as "the queen of the scenes". This essay aims to inventory Machado's ideas on the theater and his habits as a spectator by studying his observations on the actress's work, hitherto disregarded by specialists.
\end{abstract}

Keywords: theatre public formation; Machado as a theatre spectator; Adelaide Ristori. 
[...] eu fui (me, me adsum), eu fui um dos cavalos temporários do carro da prima-dona, nas noites da bela Norma! Ó tempos! ó saudades! [...]

A Candiani não cantava, punha o céu na boca, e a boca no mundo. Quando ela suspirava a Norma era de pôr a gente fora de si. O público fluminense, que morre por melodia como macaco por banana, estava então nas suas auroras líricas. Ouvia a Candiani e perdia a noção da realidade.

Machado de Assis, 15 de julho de 1877, Ilustração Brasileira

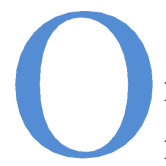
desempenho de Machado de Assis como espectador de teatro tem recebido atenção dos estudiosos, seja por meio do mapeamento das ideias que ele enunciou como folhetinista, em vários veículos (entre 1856 e 1866), e como censor do Conservatório Dramático (1862-64), seja pelo destaque dos nexos intertextuais entre tais ideias e sua literatura, especialmente a dramática. A qualidade da dramaturgia de Machado de Assis, ainda que embrionária, se conferida no conjunto amplo da sua produção, não deixa dúvida quanto ao fato de que ele era um homem de teatro e espectador assíduo, até mesmo um apaixonado. Ao tomar assento nos teatros da corte ou em seu escritório, Machado estava no domínio das convenções cênicas da época e nutria algum tipo de gosto: mesmo que se esforçasse para não tomar partido, fazia parte de um público.

No início de sua carreira como redator de folhetins (publicados de forma anônima ou sob pseudônimo, como era de praxe nos jornais da época, nos quais o cronista escrevia de tudo, desde editoriais até releases), seu juízo revelava-se por meio da frequente condenação de gêneros de mero entretenimento, cujos recursos burlescos afastariam espectadores das boas produções. Nesse grupo, que julgava pequeno, Machado apreciava obras "modernas" como as comédias realistas (na maioria, francesas) ${ }^{1}$ apresentadas em português no Ginásio Dramático, a partir de 1855, muito mais do que o velho repertório de tragédias neoclássicas e melodramas, oferecido por João Caetano no Teatro Imperial São Pedro - ambos esses teatros situados nos

\footnotetext{
${ }^{1}$ Os autores mais frequentados eram Dumas filho, Girardin, Legouvé, Augier e Feuillet.
} 
arredores do largo do Rossio (atual praça Tiradentes), onde se reunia boa parte do público frequentador de atrações noturnas da capital. Enredos que preservassem as virtudes burguesas (fidelidade, inteligência, honestidade) e suas instituições (casamento, família, trabalho) do ataque perpétuo dos vícios (adultério, prostituição, ócio, agiotagem, corrupção) inspiravam-lhe especial louvor, por terem valor de regeneração moral. "O maniqueísmo servia perfeitamente ao propósito moralizador, uma vez que o embate resultava sempre na vitória esmagadora do bem", comenta João Roberto Faria (2004, p. 302). A ideia de que o teatro pudesse ser útil, não só como espelho do real, mas também como instrumento para o seu aprimoramento, sugeria a Machado a imagem do palco como tribuna e até mesmo como púlpito.

[Tendo] o drama [...] uma missão nacional, [...] também o poeta tem cargo d'almas. Cumpre que o povo não saia do teatro sem levar consigo alguma moralidade austera e profunda. A arte pura [...] não exige tudo isso do poeta; mas no teatro não basta preencher as condições da arte. (ASSIS, 1861, p. 2)

Crítica e criação estariam na linha de frente de uma mesma missão civilizatória, na qual a "palavra eloquente de um chefe é muitas vezes necessária para reavivar as forças exaustas e reerguer o ânimo abatido", como escrevia Machado, correspondendo-se com José de Alencar, em 1868, após elogiar a ininterrupta produção do colega: "A tarefa da crítica precisa destes parabéns; é tão árdua de praticar, já pelos estudos que exige, já pelas lutas que impõe" (ASSIS, 2001a, p. 413). Tal "tarefa da crítica" lhe parecia mais árdua quando aplicada às artes dramáticas do que quando aplicada à poesia, sendo esta uma arte "pura", argumentava Machado, na tradição do pensamento romântico, que a contrapunha às artes "úteis", como o teatro. A crítica de teatro comportava um pensamento público e uma postura política, principalmente no contexto de uma nação recém-constituída, que mirava apresentar-se ao mundo como progressista, apesar de ainda estruturada em instituições coloniais. Quais lutas um crítico de teatro precisava assumir era tema frequente de conversas, no círculo de amizades de que Machado se tornara fiel, ao adentrar a elite intelectual, primeiro como cronista e folhetinista, depois como romancista. A turma se reunia, redações afora, na Sociedade Petalógica, que tinha sede na livraria de Francisco de Paula Brito, no mesmo largo do Rossio onde juntava-se o público das estreias teatrais. Diversos assuntos eram comentados, lembra Machado: "Queríeis saber do último acontecimento parlamentar? [...] Da nova ópera italiana? Do novo 
livro publicado? [...] Da última peça de Macedo ou Alencar? Do estado da praça? Dos boatos de qualquer espécie? Não se precisava ir mais longe, era ir à Petalógica" (ASSIS, apud MARTINS, 1978, p. 499). A livraria funcionava também como tipografia: ali se imprimiam e vendiam ingressos, livretos bilíngues e folhetos com árias conhecidas das óperas em cartaz. Sócios lançavam campanhas para financiar temporadas de ópera e para organizar festas em benefício de artistas estrangeiros em turnê. Mas a ocupação principal deles era articular, nesses espaços, suas cruzadas intelectuais, enquanto "juízes da arte", vale dizer formadores de opinião, atuantes em diversos meios de comunicação (como o Jornal do Commercio, o Diário do Rio de Janeiro e as revistas La Fama e Marmota Fluminense, publicada pelo mesmo Paula Brito, dono da livraria). Uma dessas cruzadas dizia respeito às normas de urbanidade que deveriam ser observadas no teatro. Segundo afirma um cidadão que assina como "A Civilização", em publicação do Diário endereçada "ao Exm. Sr. chefe de polícia", o teatro,

se antigamente se frequentava para rir e fazer barulho, hoje é um lugar sério, sobremaneira o Lírico, onde vamos para ouvir o canto e gozar do espetáculo do convívio de gente distinta e belas mulheres, em um grande salão iluminado; tais emoções são próprias de uma seleta sociedade, enquanto a confusão criada nas galerias é inconveniente, ainda mais em presença de Suas Majestades Imperiais. (A CIVILIZAÇÃO, 1855, p. 2)

$\mathrm{Na}$ falta de estádios e de um parlamento democrático, os diletantes, ou amantes da arte, frequentavam salas de espetáculos com um frenesi de militância partidária; especialmente quando se tratava do repertório lírico, ao qual se referiam com a expressão italiana bel canto independentemente da nacionalidade dos intérpretes. A predileção por uma ou outra cantora motivava verdadeiras rixas entre torcidas opostas: em nome de Madame Stoltz, de Emma La Grua, da controversa Charton-Demeur ou da sublime prima donna Augusta Candiani, espectadores encaravam batalhas campais nos saguões e nas galerias dos teatros, à base de arremesso de hortaliças, insultos, estalinhos e duelos poéticos. Na saída não faltavam carreatas com cavalos humanos, como descrito por Machado (me, me adsum) e fogos de artifício. Eram os tempos áureos do teatro na corte, que Machado viveu com paixão e narrava com saudade: 
Uma noite a ação travou-se entre o campo lagruísta e o campo chartonista, com tal violência, que parecia uma página da Ilíada. Desta vez, a Vênus da situação saiu ferida do combate; um estalo rebentara no rosto da Charton. O furor, o delírio, a confusão foram indescritíveis; o aplauso e a pateada deram-se as mãos, - e os pés. A peleja passou aos jornais. "Vergonha eterna (dizia um) aos cavalheiros que cuspiram na face de uma dama!" - "Se for mister (replicava outro) daremos os nomes dos aristarcos que no saguão do teatro juraram desfeitear Mlle. Lagrua." "Patuleia desenfreada!" - "Fidalguice balofa!" (ASSIS, 1874, on-line)

Tais guerras teriam demandado uma avaliação serena; mas o fanatismo provocava reações excessivas, tanto nos elogios como na censura, de modo que não era raro (notou então um visitante italiano) "ver passar os espectadores de um partido a outro sem razão, por mero capricho, ou por instigação daqueles que agem à surdina" (LA FAMA, 1856). Diante de possíveis provocações insurrecionais, era frequente a irrupção da polícia, que dava voz de prisão aos espectadores mais agitados ou a artistas que atendessem repetidas chamadas à ribalta. Entretanto, mesmo que isso envergonhasse a seleta sociedade, certo abalo era inevitável, já que o ingresso garantia ao comprador o direito de patear (bater os pés no assoalho), caso desaprovasse a execução, que podia ser assim prejudicada e até mesmo interrompida. Não surpreende que divos e divas oferecessem bailes de máscaras para promover as respectivas torcidas e que mesmo a venerada Candiani tivesse que abonar benefícios (réplicas suplementares) e publicar anúncios a pedido visando "agradar assim cada vez mais os dilettanti". ${ }^{2}$ Dos saguões aos salões, das livrarias aos folhetins, o debate sobre dinâmicas de produção e recepção extravasava em juízos de valor, no tocante ao comportamento das plateias e, também, às qualidades (virtudes ou vícios, literários e morais) dos repertórios. A palavra "civilização" dominava não só a seção de artes dos jornais, mas também as colunas sociais, e pipocava nas cartas publicadas a pedido dos leitores, onde ecoavam os escândalos dessas noitadas teatrais.

As salas de espetáculo, marcadas por excepcional exibição de etiqueta, eram consideradas palco para ascensões individuais, mas também para a afirmação de certa ideia de nacionalidade. Tratava-se, no Segundo Reinado, de concretizar um projeto de independência cultural, que coroasse a independência política (1822). Para tanto, o governo imperial financiava as

2 “Communicado", assinado por Zanguinha, publicado no Jornal do Commercio (1845, p. 2). 
temporadas de ópera mediante loterias ou parcerias com sociedades de amadores, que gozariam do usufruto de camarotes; além disso, promovia iniciativas para difundir a arte entre classes menos abastadas (MINISTÉRIO DO IMPÉRIO, 1852, on-line). Em 1856, o imperador subsidiou a fundação da Imperial Academia da Ópera Nacional, que manteve até 1863, com o objetivo de cultivar talentos nativos. Não era só por melomania, portanto, que Suas Majestades Imperiais honraram as estreias com suas presenças, sendo esse fato anunciado nos cartazes. De acordo com a composição prevista pela arquitetura dos teatros edificados à época, os ocupantes da tribuna imperial seriam vistos por espectadores de classe média sentados no parterre e por assinantes, acomodados nos camarotes, entre os quais intelectuais e formadores de opinião, que poderiam assim mostrar afinidade com os gostos do soberano, imitando suas atitudes; todos também seriam vistos pelo povo, apinhado em pé nas galerias, sob o controle da polícia, que evitava tumultos. A sala de espetáculos como um todo compunha um outro espetáculo, ordenado conforme um regime de visibilidade em que tarefas e papéis eram atribuídos a cada ator social.

Assim, não surpreende que Machado de Assis, comentando as desordens da noite anterior, indague se não deveria "a culpa ser lançada ao teatro [e] ao público [pois] o público é uma criança que se educa; o teatro [...] é um meio de vida que se exerce" (ASSIS, 1865, p. 1). Seria então tarefa dos intelectuais fazer do teatro uma "iniciativa de civilização" e correição moral, da qual o público-criança seria destinatário, mas que engajaria toda a assembleia teatral como um laboratório social.

[...] a arte não deve desvairar-se no doido infinito das concepções ideais, mas identificar-se com o fundo das massas; copiar, acompanhar o povo em seus diferentes movimentos, nos vários modos e transformações da sua atividade.

Copiar a civilização existente e adicionar-lhe uma partícula é uma das forças mais produtivas com que conta a sociedade em sua marcha de progresso ascendente. (ASSIS, 2001b, p. 489)

Missão civilizatória era a que Quintino Bocaiuva, mentor de Machado na ocasião de sua contratação pelo Diário (1859), atribuía ao teatro, cujo fim não seria só "divertir e amenizar o espírito, mas, pelo exemplo de suas lições, educar e moralizar a alma do público" (BOCAIUVA, 2001, p. 447-461). A ideia de que um povo, indo ao teatro, pudesse elevar seu "grau de civilização" embasava também o conceito de "daguerreótipo moral" que José de Alencar 
aplicava, no mesmo fim de década, à cena moderna, e que seria ferramenta de uma pedagogia social ampla quando se tornasse "verdadeira". No tablado e nas plateias, insinua um jovem Machado então aderindo à cruzada da elite intelectual na qual adentrava, seria preciso discernir a "perniciosa existência entre nós de alguns frenéticos apreciadores da farsa antiga" (ASSIS, apud FARIA, 2004, p. 300). Tal divisão, nas plateias que frequentavam os mesmos teatros dos arredores do largo do Rossio (por aqui, frequentadores de farsas e outros gêneros ligeiros; por ali, frequentadores de óperas, dramas, tragédias), ia constituindo, por volta de 1850, um duplo público, com gostos e comportamentos tão diversos que motivavam uma forte concorrência, em um mercado ainda em formação. A coexistência dessas plateias diversas, para as quais direcionavam-se as ações artísticas e críticas, embasou modos de produção e consumo que estariam ainda em vigor um século mais tarde, na década de 1950, quando críticos se veriam novamente às voltas com a tarefa de demarcar o que seria vanguarda e o que seria entretenimento, ${ }^{3}$ no âmbito da produção moderna. Nos dois casos (seja da reforma que se deu com a instalação do Ginásio Dramático no Rio de Janeiro, na metade do século XIX, seja da renovação da cena paulista em torno do Teatro Brasileiro de Comédia, na metade do século $\mathrm{XX}$ ), a proposta realista teve função estratégica, mais do que meramente pedagógica, pois dotava as produções de qualidades que agregavam as duas plateias. O realismo acabou se impondo, então, como "gosto médio".

Os críticos do ambiente intelectual que Machado frequentava, diante da escassa ocorrência de produções nacionais que correspondessem aos seus esforços civilizatórios e, por outro lado, da persistente predominância da dramaturgia francesa (seja no âmbito sério, com peças realistas importadas pelo Ginásio Dramático, seja no âmbito do entretenimento, com vaudevilles, dramalhões, farsas e outras produções boulevardiers, que se julgavam até mesmo perniciosas), tiveram que amenizar seus propósitos. No começo da década de 1860, desistiram do intransigente modelo do "daguerreótipo moral" e passaram a validar peças que retratavam, de modo indulgente, detalhes da vida burguesa, os ditos "dramas de casaca", e até mesmo peças bem-humoradas, que recapitulavam casos escandalosos da sociedade local, as "revistas do ano". Era evidente que tais produções alcançavam um grande público, agradando a faixas sociais diversas. Alencar apreciou a dramaturgia ligeira e inconsequente das populares revistas de Artur de Azevedo, desde as

\footnotetext{
${ }^{3} \mathrm{Na}$ terminologia crítica da década de 1950, haveria uma produção de peças "para pensar" e outra de peças "inconsequentes" para agradar as respectivas plateias.
} 
primeiras provas (O Rio de Janeiro de 1887), por considerar que combinariam com os anseios da plateia; a mesma plateia que, poucos anos depois, rejeitou o repertório simbolista considerado moderno na Europa, Ibsen in primis. ${ }^{4}$ Machado compreendeu com tempestividade que somente a empatia, de que o estilo naturalista era capaz, inspiraria sentimentos proativos nos espectadores, bastando então à obra, para ser moral, que "a impressão que [dela] se recebe [seja] favorável ao aperfeiçoamento da alma humana", como escreveu em 1865 (ASSIS, apud FARIA, 2004, p. 323).

Mesmo lamentando o excesso de traduções do francês (chegando a propor um imposto sobre peças traduzidas), desde 1858, em "O presente, o passado e o futuro da literatura brasileira", Machado instigava o surgimento de uma dramaturgia nacional que tivesse o realismo francês por modelo e o estudo da sociedade local por conteúdo. Atribuía a responsabilidade pelo descaso com que se tratava o teatro na capital, se não ao público que se limitava a consumir o que lhe fosse dado, à cobiça dos empresários e à vaidade dos artistas; e não temia desaprovar João Caetano, que em seu repertório de dramalhões levava à cena uma anacrônica galeria de "múmias" (como Machado as descrevia), de fisionomia carregada, voz impostada, gestos arrebatados e outros exageros típicos dos histriões românticos, habituados a qualificar seu mérito pela quantidade de abalos nervosos infligidos aos espectadores. Preferia desempenhos menos enfáticos (como o de Furtado Coelho, entre os atores do Ginásio que buscavam a naturalidade, em cenas de realismo minucioso, quase minimalista) e mais austeros (como o da portuguesa Ludovina Soares da Costa, "trágica eminente" cuja performance compensava os "desvarios da velha escola"). Militava, insistia, desabafava:

Qual é o homem de gosto que atura no século XIX uma punhalada insulsa tragicamente administrada, ou os trocadilhos sensaborões da antiga farsa?

[...] Removidos os obstáculos que impedem a criação do teatro nacional, as vocações dramáticas devem estudar a escola moderna. Se uma parte do povo está ainda aferrada às antigas ideias, cumpre ao talento educála, chamá-la à esfera das ideias novas, das reformas, dos princípios dominantes. É assim que o teatro nascerá e viverá; é assim que se há de

\footnotetext{
${ }^{4}$ Os espectros, apresentado no Rio de Janeiro por Ermete Novelli em 1895, foi um fracasso tão sonoro que a crítica ficou constrangida a elogiar a obra do dramaturgo até mesmo quando proposta por Eleonora Duse em 1907 (Hedda Gabler).
} 
construir um edifício de proporções tão colossais e de um futuro tão grandioso. (ASSIS, 2013, p. 68)

Deslocando a questão do valor moral para uma dinâmica "moderna" de reforma do gosto, o espectador Machado foi requalificando até gêneros considerados "baixos" na plataforma hierarquizada (que partia das tragédias, descendo aos dramas românticos e comédias realistas, até chegar às revistas e farsas), que até então costumava adotar em sua atuação como crítico: "Entendo que o belo pode existir mais revelado em uma forma menos imperfeita, mas não é exclusivo de uma só forma dramática. Encontro-o no verso valente da tragédia, como na frase ligeira e fácil com que a comédia nos fala ao espírito" (ASSIS, apud FARIA, 2004, p. 314).

Se considerarmos a intransigência com a qual poucos anos antes, na função de censor, havia sugerido vetar a apresentação pública de peças que ele julgava mal escritas (ou mal traduzidas), indecentes quando comédias, incongruentes quando dramas, capazes, segundo ele, de ofender a dignidade do tablado e, mais, de "perverter o gosto e [...] contrariar a verdadeira missão do teatro" (ASSIS, apud FARIA, 2004, p. 320), a militância machadiana parece mesmo ter desenhado uma parábola descendente. Seu afastamento da atividade de crítico teatral em 1865, que coincidiu com a inauguração do Alcazar Lírico (com Orphée aux enfers, opereta francesa com música de Offenbach, de 1865), vela certa desilusão com a missão civilizatória que havia animado suas iniciativas anteriores. É fato que Machado, naquele ano, noticiou o falecimento do teatro nacional e prefigurou a "completa dissolução da arte", caso não fossem tomadas medidas eficazes para a sua manutenção. Finda a temporada da arte útil, que talvez fosse capaz de realizar uma interlocução civilizatória com a sociedade, sobraria à nação somente uma diversão "para desenfastiar o espírito, nos dias de maior aborrecimento". Em desespero, cobrava a intervenção normalizadora do governo, que, assim como "sustenta uma academia de pintura, arquitetura e estatuária, não achará razão plausível para eximir-se de criar uma academia dramática, uma cena-escola, onde as musas achem terreno digno delas, e que possa servir para a reforma necessária no gosto público" (ASSIS, 2001d, p. 557-562). Em nada adiantou esse apelo derradeiro, uma vez que, em seu balanço da literatura brasileira de 1873, Machado decidiu celebrar o funeral anunciado, reduzindo o assunto a "uma linha de reticência".

Não há atualmente teatro brasileiro; nenhuma peça nacional se escreve, raríssima peça nacional se representa. As cenas teatrais deste país 
viveram sempre de traduções, o que não quer dizer que não admitissem alguma obra nacional quando aparecia. Hoje, que o gosto público tocou o último grau da decadência e perversão, nenhuma esperança teria quem se sentisse com vocação para compor obras severas de arte. Quem lhas receberia, se o que domina é a cantiga burlesca ou obscena, o cancã, a mágica aparatosa, tudo o que fala aos sentimentos e aos instintos inferiores? (ASSIS, 2001c, p. 569-570)

Durante esse intervalo de tempo, em 1869, uma pontada de entusiasmo interrompeu a parábola descendente. Ela coube nos quatro folhetins dedicados à temporada carioca da atriz italiana Adelaide Ristori, publicados sob o pseudônimo de Platão e recolhidos no volume Homenagem a Ristori, editado no mesmo ano pela assessoria de imprensa da atriz, onde a autoria é atribuída ao "distinto literato" Francisco (sic) Machado de Assis. ${ }^{5}$ Citadas por Edoardo Bizzarri (1961) e republicadas no volume Uma amizade revelada (VANNUCCI, 2004), juntamente com a correspondência entre a atriz e o imperador Pedro II, trocada ao longo de quarenta anos de amizade, as resenhas descrevendo em pormenores o repertório e a atuação daquela que era universalmente estimada como a rainha da cena trágica são mais do que entusiastas: são eufóricas, hiperbólicas. Mesmo antes de assisti-la, Machado compartilhava da admiração que ela suscitou junto aos seus colegas americanos, quando da passagem de Ristori pelos Estados Unidos, em setembro de 1866. Em carta de 29 de outubro daquele ano a Bocaiuva (TRAVASSOS, 1931), Machado pede opinião sobre os méritos da atriz - a quem, àquela altura, ele supõe que o amigo, então viajando pela Europa, certamente teria dado um jeito de assistir. Em Nova York, a sala lotada do Théâtre Français apesar da chuva torrencial, os triunfais aplausos e a ousadia de apresentar em italiano a Medea (na versão "moderna" de Légouvé) haviam consagrado uma noitada, a partir da qual se teria que datar - como estampou o Herald Tribune - a "nova era da arte dramática neste país. Não há palavras que façam jus à perfeição. Atributos como grande, magnífica, soberba, sublime soam inadequados perante Ristori e sua arte" (NEW YORK HERALD TRIBUNE, 21 set. 1866 apud BASSNETT; BOOTH; STOKES, 1996, p. 163).

\footnotetext{
5 Mesmo não recolhidos nas Obras, os folhetins publicados com o pseudônimo Platão foram republicados em 1955 pela Academia Brasileira de Letras com a atribuição de autoria motivada pelo fato de que "não se sabe de outro Machado de Assis que ali [no Diário do Rio de Janeiro] escrevesse" (LIMA SOBRINHO, 1955)
} 
Para a estreia no Rio de Janeiro, no Teatro Lírico Fluminense, em julho de 1869, Ristori elegeria mais uma vez o "terrível papel" (SEMANA ILUSTRADA, 1869, p. 18) recusado pela diva trágica francesa, Mme. Rachel, para quem Légouvé o escrevera em 1854, e que dois anos mais tarde, por ocasião de sua primeira temporada em Paris, Ristori havia acolhido em seu repertório, sob a condição de cortar a cena do assassinato dos filhos. Desde quando ousara desafiar a supremacia da grande tragedienne em seu próprio território, a petite italienne (assim fora alcunhada Ristori pelos temidos críticos franceses) costumava abrir com Medea sua galeria de nobres heroínas (Mirra, Pia de Tolomei, Francesca da Rimini, Maria Stuart) devotadas ao bem da pátria e ao bem em geral. Mais uma havia sido aprontada para a turnê americana, que teve lugar após as passagens por Londres e Madri: nada menos que Elizabeth, peça sobre a formidável rainha inglesa, composta para a ocasião pelo dramaturgo italiano Paolo Giacometti. O status social de Ristori aumentava também em virtude do jogo de reflexos, primorosamente calculado, entre imagens de rainhas e imagens da própria atriz, que de figlia d'arte (ou seja, descendente de família de artistas) havia se tornado nobre, após casar (por amor) com o marquês Capranica del Grillo. $\mathrm{O}$ prestígio de suas distintas amizades, amplificado pela imprensa mundial (devidamente informada por meio de livros, libretos e álbuns fotográficos, que ela mesma mandava publicar e distribuir nos países interessados em futuras temporadas suas), acabava atribuindo a ela o título, não já de marquesa, mas de rainha, mesmo que no reinado simbólico dos palcos. Escreveu um crítico carioca:

O triunfo que a exímia trágica alcança sobre a cena não é menos brilhante do que o da poderosa rainha [Elizabeth] sobre a armada espanhola, tendo tido esta em seu auxílio o valor britânico e o furor da tempestade, ao passo que a rainha do palco só tem a sua inspiração e os seus admiradores. (P.A.L., 1869b, p. 145)

No número dos admiradores constava, naturalmente, o imperador $\mathrm{d}$. Pedro II, acomodado com a esposa napolitana Teresa Cristina de Bourbon na tribuna imperial, à qual a "rainha" Ristori dirigia-se do palco, após a sua estreia, para declamar um poema que ilustrava os valores da moralidade, do patriotismo, do monarquismo e da nobreza de ânimo (VERSI DECLAMATI..., 1869, p. 191-192), e que lhe garantiu, pelo resto da vida, o favor da correspondência pessoal com d. Pedro II, radicada em sentimentos de afinidade e franca amizade. No farto material para divulgação, de qual 
cuidava pessoalmente, a atriz combinava os números triunfais de seu sucesso artístico com narrativas de pequenos gestos de cidadã modelo, consciente de seus deveres éticos e sociais. Sua estratégia pessoal de ascensão social acabou contribuindo enormemente para a emancipação da classe artística, especialmente das atrizes, cuja conduta cigana e exposta, semelhante ao exercício da prostituição - a que outras figlie d'arte eram de fato obrigadas -, ainda parecia indecente. No contexto da recente unidade e independência italiana (1860) sob a monarquia dos Savoia, a trajetória única de Ristori propagava-se como uma espécie de movimento moralizador de uma classe que era convocada a contribuir para o progresso da nação, assumindo a tarefa de formação da consciência nacional e, por meio das temporadas dos grandes atores, repercutindo no exterior a imagem da Itália como celeiro do gênio e da cultura. Tal imagem não ficou desprovida de sentido, quando projetada no contexto brasileiro do Segundo Reinado, onde, como vimos, a construção da desejada "civilização" se daria nos palcos e, por reflexo, no comportamento das plateias. Aqui como lá, o teatro integraria uma peculiar ideia burguesa de nação, ao mesmo tempo cortesã e liberal. Entende-se bem, então, o reiterado entusiasmo de Machado diante da oportunidade de estabelecer o consenso do público em relação à missão moralizadora da arte, desqualificada pela pouca-vergonha das farsas, dos dramalhões e das concorridas operetas do Alcazar, que a reduziam a império da diversão. Parodiando seus próprios anúncios fúnebres anteriores, Machado resolveu ressuscitar a musa trágica para descrever a primeira aparição de Ristori no tablado tupiniquim:

Davam por morta a arte antiga [...]. Testemunhas insuspeitas afirmavam ter assistido ao fatal passamento, que, segundo uns, ocorreu naturalmente, e segundo outros, foi o resultado de um golpe, que desfechou na mísera e mesquinha um galhardo bandido espanhol. O que havia de certo é que estava morta. [...]

Não se lhe rezou responso, que a finada não era cristã. [...]

Pois não é verdade. A musa não morreu, nem podia morrer. Quando a davam por morta, atravessava a terra com as feições da imortal Ristori. [...]

É supérfluo comemorar aqui os aplausos que Ristori tem merecido por toda parte onde quer que vai manifestar os admiráveis rasgos de seu gênio. Ninguém tem o direito de ignorar a Ristori; é uma dessas figuras que se impõe à admiração dos povos, e cujo nome, como uma larga auréola, vai além do teatro de seus triunfos. (ASSIS, 2004a, p. 274) 
No ideário do qual, enquanto espectador, Machado comunga, a hegemonia italiana no campo do bel canto havia sido alimentada por décadas de consagrações de prime donne em turnê. Por ser oriunda da península (um tópos simbólico para ele, que nunca havia viajado para lugar algum), região que era considerada berço das artes clássicas e da lírica, Ristori lhe parecia constituir o maior ícone da feliz convivência entre civilizações humanistas:

A imaginação pública criava uma Ristori dotada de qualidades superiores; mas aqui a realidade foi além da imaginação. Estou que ninguém calculou ao certo encontrar tão peregrino gênio unido a tão acabada perfeição. [...]

Poucas vezes tem a natureza sido tão pródiga como foi com esta sua ilustre filha. Não se contentou com o gênio que lhe deu, gênio superior entre os primeiros; deu-lhe uma figura maravilhosamente adaptada ao teatro; figura imponente, escultural, rosto severo, voz sonora e vibrante, que possui todos os tons do sentimento, desde a indignação até a ternura. Depois [...] fê-la nascer na Itália, terra clássica da arte, onde a cada passo se encontra um monumento e uma tradição, e cuja língua, harmoniosa entre todas, é um dos mais cabais instrumentos da palavra humana. (ASSIS, 2004a, p. 274)

Melômano, como ele mesmo se descreve, Machado preferia compositores italianos: enlouquecia por Bellini, como a maior parte da plateia carioca, mas alimentava uma especial admiração por Giuseppe Verdi, a quem atribuía o mérito de ser patriota, por ter contribuído, com suas obras, para a unificação e construção da nação - um processo político em relação ao qual Machado alimentava o maior interesse. ${ }^{6}$ Essas predileções são sintomas de um sentimento platônico, declarado ao amigo Joaquim Nabuco, os dois já idosos, quando confessa ter sido seu sonho desde a mocidade a viagem romântica à Itália, aquela "terra amassada de tantos séculos de história do mundo" (Carta de 20 de abril de 1903 - ARANHA, 1923, p. 12). O hábito da leitura direta em italiano (como prova Bizzarri [1961]) colocava Machado na condição privilegiada de compreender o conteúdo de óperas e dramas sem ter que recorrer aos libretos; mesmo assim, gostava de repetir que entendia italiano por música, como no comentário à temporada da Eleonora Duse, em 1885:

\footnotetext{
6 "Senador! Aqueles italianos são artistas até nas eleições" foi o comentário de Machado à notícia da eleição do compositor ao Senado, em 1876. "Nós somos eleitores até nas artes. [...] A Itália está convencida que ele será melhor maestro que político; mas sabe que é patriota e não lhe pede mais. Boa Itália! Aquilo é o país artista por excelência" (ASSIS, 1876, p. 142).
} 
[...] eu só entendo italiano cantado, e a Duse-Checchi não canta. Fui lá algumas vezes levado pelo que ouvia dizer dela e da companhia; fui, gostei muito do diabo da mulher, fingi que rasgava as luvas de entusiasmo, para dar a entender que sabia daquilo; nos lugares engraçados ria que me escangalhava, muito mais do que se fosse em português; mas, repito, italiano por música. ${ }^{7}$ (ASSIS, 1885, p. 2)

No caso de Ristori, pelo contrário, o público se encantava com "a beleza musical de uma voz sentimental para exprimir o amor, a ternura, as mágoas d'alma com tal certeza, que, por uma mágica ilusão, parece que se está assistindo a uma representação lírica" (P.A.L., 1869a, p. 55), algo que, na opinião geral, nem Mme. Rachel possuía. De fato, a atriz italiana era frequentemente mencionada ao lado cantoras, o que lhe garantia um domínio incomparável, pois, no canto, a empatia independe da compreensão do conteúdo.

Para que simplesmente declamando possa uma italiana fazer delirar de entusiasmo, chorar de emoção, estremecer de terror russos, alemães, ingleses e outros cuja língua não tem menor analogia com a dela, é um talento como poucos pode criar a natureza. Se ao simples nome da Ristori os teatros se enchem em países onde o povo não leva consigo a esperança de compreender uma só palavra [...] como não sucederia o mesmo [...] entre nós que falamos essa língua na qual quando imagina com pouca corrupção crê que é latina, latina de que é filha primogênita a italiana? (OLIVEIRA E CASTRO, 1869, p. 62)

Ristori reinava entre as prime donne, pois era capaz de ampliar o alcance de sua potência dramática, apropriando-se desta e de outras características do gênero lírico, como a execução ao vivo de música original, confiada às orquestras locais contratadas. $\mathrm{O}$ acompanhamento the permitia preencher sua presença cênica de efeitos vocais (variações, trêmulos, respiração) capazes de expandir verticalmente a palavra declamada em partitura harmônica. Graças a tal virtuosismo, ocupava o domínio tradicional do melodrama, embora contrariando, com seu absoluto rigor, a gestualidade desenfreada típica daquele gênero. Verdi em pessoa a apontava como modelo às suas cantoras: "quem viu Ristori sabe que não tem de se fazer senão

\footnotetext{
7 Dez anos mais tarde, em 13 de outubro de 1895, Machado repete a brincadeira ao contar que um imigrante, trepado na estátua de d. Pedro I, havia tentado arengar o povo lá de cima, mas, por falar na língua materna, ninguém o entendia, pois "nós só [entendemos] italiano por música" (ASSIS, 1895, p. 1).
} 
pouquíssimos gestos, aliás, tudo se reduz a um gesto só: que é [na cena do sonambulismo de Lady Macbeth, tragédia shakespeariana da qual o compositor havia tirado em 1847 a ópera Macbeth] o de apagar a mancha de sangue que ela crê ter na mão" (MELDOLESI, 1983, p. 15). Ristori conseguia tal intensidade plástica, reduzindo ao mínimo a marcação, ou seja, aplicando procedimento oposto ao adotado pela maioria dos grandes atores românticos, que exageravam expressões e gestos, para que esses fossem percebidos por públicos gigantescos, ou por mero vício de overacting (vale dizer, aquela coloração excessiva das reações que Machado cominava a João Caetano). A sabedoria vocal e o minimalismo gestual de Ristori proporcionavam à atriz um domínio rítmico que se traduzia junto ao público na sensação de um espantoso controle da cena.

Em sua estreia carioca, aparecendo em cena coberta pela vasta capa preta de Medea, Ristori recebeu, inesperadamente, uma "glacial acolhida":

Não um aplauso, um murmúrio de agrado! Esta frieza inesperada me deixou estupefata, pois a fama da gentileza daquele público é conhecida. Mas ouçam como, ao primeiro efeito meu, o entusiasmo dissipou a frieza! Quando Medea, desesperada ao ouvir as lamentações dos filhos pedindo pão, exclama Nutritevi, bevete il sangue mio, a invocação, saindo impetuosa dos meus lábios e do meu coração, suscitou um frêmito na plateia que cresceu e explodiu num daqueles aplausos que consagram um grande sucesso. (RISTORI, 1887, p. 102)

Eis como o efeito é descrito por um espectador:

Ela aproxima-se a passos lentos, sua boca abre-se, sonoros, cheios e vibrados por uma voz de melodioso timbre, repassados com indizível expressão caem os primeiros versos no ouvido do público, e de todos os ângulos prorrompem os bravos e as palmas, crescendo sempre até que um verdadeiro frenesi parece haver-se apoderado de todos. (OLIVEIRA E CASTRO, 1869, p. 62)

Nesse contexto de universal veneração das qualidades vocais da atriz, o espectador Machado compreende, descreve e elege outras qualidades, para destacar o apuro com que ela, com um só gesto, sozinha em cena, domina os instintos não inteiramente civilizados daquela plateia apinhada, fazendo-a transpor o abismo de séculos e oceanos de distância. 
Que inúmeras cordas tem a sua lira! A dor, a cólera, o desdém, o amor, a ironia, o desespero, o ciúme, que longa escala de sentimentos nessa Medea, e como Ristori os sabe exprimir com tão artística verdade! Tem para isso uma voz magnífica, vibrante, apaixonada. E que direi daquela fisionomia, que se presta, como a voz, a todas as modificações do sentimento? [...]

[...] Uma contração do rosto, uma expressão dos olhos vale às vezes um discurso inteiro, e ninguém melhor que Ristori possui esse dom de fazer-se entender pelo gesto aos que não podem entendê-la pela língua.

[...] Cada gesto, cada passo, cada movimento revela uma intenção plástica e dá sempre uma atitude artística. Ela compreende que, sem a atitude, a personagem seria incompleta; mas, como é artista de seu tempo, e criadora, compreende também que a atitude e a dicção no teatro devem despir-se de todo tom afetado ou nimiamente convencional. [...]

Falei nos aplausos que Ristori tem recebido; entenda-se, porém, que eu incluo nesta expressão as palmas e as lágrimas, os murmúrios e os silêncios. Há momentos em que a sanção pública está nos olhos úmidos e nos corações palpitantes. Que lágrimas nos arranca ela nos momentos de seus desesperos de mãe! $\mathrm{E}$ todavia, no meio do delírio da personagem, vê-se que ela conserva perfeita calma da sua consciência, princípio absoluto da arte, que nenhum talento esquece sem comprometer a sua personalidade.

[...] Medea comovia as mães gregas como comove as mães brasileiras; é porque qualquer que seja a crosta da civilização, palpita debaixo o coração humano. E note-se mais; as paixões da tragédia geralmente são violentas em seus resultados; mas em si são idênticas às paixões da vida. (ASSIS, 2004a, p. 274-275)

Aqueles "silêncios", durante os quais o corpo coletivo do público fica suspenso e capturado pelo corpo palpitante da atriz, são a ocasião para uma espécie de moderna catarse: uma regeneração física e moral dos espectadores, no momento em que aderem à universalidade dos sentimentos mostrada pela "atitude" da atriz. É nessa potência estética controlada que Machado situa o trono de Ristori, para o qual não acha concorrência a não ser no grande Garrick (por ele conhecido só por fama):

Muitas rainhas lhe deram para ocuparem com ele o trono da arte [...]; mas de todas a que pode legitimamente ser sua esposa na imortalidade é Ristori. Assim o reconheceu a crítica francesa, apesar de contar a França talentos, como Champsmeslé, Clairon, Mars, Rachel; a todas 
venceu a divina italiana. [...] Ristori é um modelo que se deve estudar, não imitar: imitá-la seria cometimento impossível. (ASSIS, 2004a, p. 275)

[...] parece [...] que essa majestade que lhe respira da palavra e do gesto, aprendeu-a na convivência dos príncipes. (ASSIS, 2004c, p. 278)

Nos sucessivos folhetins, dedicados a Pia de Tolomei - Judith (10 jul. 1869), a Maria Stuart - Isabel de Inglaterra - Phoedra (18 jul. 1869) e a Soror Thereza - Myrra - Estalajadeira (30 jul. 1869), Machado estuda com afinco a técnica e o estilo da atriz, uma "artista consumada" cuja "natural moralidade" julga impossível imitar. "Vê-se que ela analisa o caráter de um papel antes de estudá-lo, e busca penetrar no âmago do drama a fim de o compreender em todas as suas partes. E onde há arte possível sem essa análise prévia?" (ASSIS, 2004b, p. 276). Interpretando papéis tão diversos, como o de mãe vingativa (Medea), de mártir inocente (Pia), de incestuosa reprimida (Myrra, Fedra), de rainha ou heroína dividida entre as leis do desejos e as leis do poder (Isabel, Judith), de mulher que luta para emancipar-se dos laços patriarcais da família e da etnia (Thereza, Cassandra), e que por vezes consegue fazê-lo (Mirandolina, a estalajadeira), a atriz parece acolher um catálogo de almas femininas inquietas e corpos nem um pouco docilizados. $\mathrm{O}$ corpo/catálogo da atriz derruba fronteiras de classe e põe em cena mulheres reais em luta por sua emancipação, sem reduzi-las a papéis "menores" ou desqualificar sua humanidade no descompasso dos gritos e da gesticulação, no caso de Mirandolina, por exemplo, por ser mulher do povo.

Pois quê! aquela rapariga, adorada por três fidalgos, e zombando de todos, astuta, graciosa, namoradeira, tão natural na sua estalagem, tão senhora do seu avental, é a mesma Stuart que ainda ontem fez tremer Isabel, a mesma Isabel que ontem mandou decapitar Stuart? É a mesmíssima Ristori, a atriz dos cem caracteres e das cem máscaras que tudo interpreta com a feição própria, que deixa a coroa nos palácios para entrar na hospedaria, e deixa as chaves na hospedaria para voltar aos palácios; é agora a comédia [...] como foi ontem a tragédia e o drama: é Ristori, enfim, que tudo sabe e tudo estudou [...] [e] não desmente Mirandolina; o caráter ia seguindo naturalmente. (ASSIS, 2004d, p. 282)

A violência das situações não assusta Machado, mesmo que escandalize outros críticos; pois o escritor aprecia as nuances psicológicas com que Ristori trata aquelas situações de modo que correspondam a situações reais e que o público "aceite" (ASSIS, 2004d, p. 281) aquela singularidade fora dos 
padrões. Interessa-lhe dar relevo à pergunta posta por um espectador, na longa carta que hospeda no Folhetim de 15 de julho: "para mim é importante saber se o teatro antigo está ou não fora de moda, se as grandes paixões descritas pela musa clássica são ou não experimentadas pela sociedade moderna. Estas violentas comoções, estes sentimentos excessivos fazem ou não vibrar de emoção o público inteiro?” (CASTELLAMMARE, 1869, p. 1) Machado compreende que o modo da interpretação pode atualizar qualquer conteúdo dramático; desta forma uma atriz se torna preciosa "colaboradora [...] que não só perscruta, entende e produz o pensamento do poeta, e o sentimento da obra, senão que lhos completa quando são falhos, ou lhos empresta quando são nulos" (ASSIS, 2004b, p. 276). Ristori em cena "não se limita a criar e multiplicar efeitos [...]: transforma situações" (ASSIS, 2004b, p. 277). Os recursos que descrevemos, como a modulação vocal, a composição psicológica e o minimalismo gestual, compõem uma técnica dramática moderna à qual Ristori subordinava a declamação, buscando um tom de interpretação realista que dotasse sua austera e poderosa presença cênica de sentimentos cotidianos. O realismo aproximaria a plateia, provocando-lhe emoções participativas mesmo diante de personagens trágicas cuja oratória poderia parecer obsoleta. Embora mantendo repertório e aura de prima donna, a atriz fazia questão de distanciar-se do modelo clássico francês que incluía sustentar o compasso mesmo em situações corriqueiras. Renegando a regra da "justa medida", Ristori procurava modernizar seu estilo de interpretação e se consagrar como porta-bandeira de outra escola.

Nós [italianas], pelo contrário, admitimos que nos pontos culminantes da paixão a pessoa se descomponha: pois, quando nos afeta uma súbita dor ou alegria, não é natural levar a mão à cabeça e mexer nos cabelos? $\mathrm{Na}$ escola italiana, acreditamos que a interpretação deve recriar ao vivo e com verdade tudo que a natureza mostra. (RISTORI, 1887, p. 40, grifo meu)

É essa arrebatadora experiência de realismo que interrompe a parábola cética de Machado. Imaginamos o espectador decepcionado que, de repente, percebe que o tablado pode ser uma sessão de vida ao vivo, mais do que um exercício de estilo ou de moral. Imaginamos o crítico teatral dado à literatura que reconhece na técnica da atriz uma linguagem artística potente, que consiste em "recriar ao vivo e com verdade" tudo aquilo que pode ser observado e estudado da vida. Eis então que, deixado para trás o ofício de 
juiz-censor, Machado absorve na escrita ficcional sua função de espectador e, atento observador da vida burguesa e urbana, mesmo que inteiramente local, dela emergem seus personagens. Estes não param de sair de casa para ir a teatros, torcer por uma ou outra diva, comentar dramas e comédias, citar falas e gestos de personagens e cantar as árias prediletas; recriando nas páginas, enfim, "ao vivo e com verdade", um mundo percebido como espetáculo.

\section{Referências}

A CIVILIZAÇÃo. Ao Exm. Sr. chefe de polícia, Diário do Rio de Janeiro, Rio de Janeiro, 6 fev. 1855, p. 2.

ARANHA, Graça. Machado de Assis e Joaquim Nabuco. São Paulo: Monteiro Lobato, 1923.

ASSIS, Machado de. Comentários da Semana. Diário do Rio de Janeiro, Rio de Janeiro, 16 dez. 1861, p. 1-2. 31 de janeiro de 1865. Diário do Rio de Janeiro, Rio de Janeiro, 31 jan. 1865, p. 1.

. A mão e a luva (1874). Disponível em: <http://www.dominiopublico.gov.br/ download/texto/bn000027.pdf >. Acesso em: 25 fev. 2019.

. História de quinze dias. Ilustração Brasileira, Rio de Janeiro, 1 nov. 1876, p. 142.

. Balas de estalo - 26 de julho de 1885. Gazeta de Notícias, Rio de Janeiro, 26 jul. 1885, p. 2.

A Semana. Gazeta de Notícias, Rio de Janeiro, 13 out. 1895, p. 1.

. Adelaide Ristori: folhetins. Rio de Janeiro: Academia Brasileira de Letras, 1955.

. Carta a José de Alencar. In: FARIA, João Roberto. Ideias teatrais. São Paulo: Perspectiva, 2001a.

. Ideias sobre o teatro (O espelho, Revista de teatro, 1859). In: FARIA, João

Roberto. Ideias teatrais. São Paulo: Perspectiva, 2001b.

. Instinto de Nacionalidade. In: FARIA, João Roberto. Ideias teatrais. São Paulo: Perspectiva, 2001c.

. O teatro nacional. In: FARIA, João Roberto. Ideias teatrais. São Paulo: Perspectiva, 2001d. p. 557-562.

. Folhetim I do Diário do Rio de Janeiro - Medea, 2 jul. 1869. In: VANNUCCI, Alessandra. Uma amizade revelada: correspondência entre Dom Pedro II e Adelaide Ristori, a maior atriz de seu tempo. Rio de Janeiro: Fundação Biblioteca Nacional, 2004a, p. 273-274. 
. Folhetim II do Diário do Rio de Janeiro - Pia de Tolomei, Judith, 10 jul. 1869. In: VANNUCCI, Alessandra. Uma amizade revelada. Correspondência entre o Imperador dom Pedro II e Adelaide Ristori, a maior atriz de seu tempo. Rio de Janeiro: Fundação Biblioteca Nacional, 2004b, p. 275-277.

. Folhetim III do Diário do Rio de Janeiro - Maria Stuart, Isabel de Inglaterra, Phoedra, 18 jul. 1869. In: VANNUCCI, Alessandra. Uma amizade revelada. Correspondência entre o Imperador dom Pedro II e Adelaide Ristori, a maior atriz de seu tempo. Rio de Janeiro: Fundação Biblioteca Nacional, 2004c, p. 277-280.

. Folhetim IV do Diário do Rio de Janeiro - Sóror Teresa, Myrra, Estalajadeira, 30 jul. 1869. In: VANNUCCI, Alessandra. Uma amizade revelada. Correspondência entre o Imperador dom Pedro II e Adelaide Ristori, a maior atriz de seu tempo. Rio de Janeiro: Fundação Biblioteca Nacional, 2004d, p. 280-282.

. O presente, o passado e o futuro da literatura. In: AZEVEDO, Maria Sílvia; DUSILEK, Adriana; CALLIPO, Daniela Mantarro (Orgs.). Machado de Assis: crítica literária e textos diversos. São Paulo, Editora Unesp, 2013. p. 61-68.

BASSNETT, Susan; BOOTH, Michael; STOKES, John. Three tragic actress: Siddons, Rachel, Ristori. New York: Cambridge University Press, 1996.

BIZZARRI, Edoardo. Machado de Assis e a Itália. São Paulo: Instituto Cultural Ítalo-Brasileiro, 1961.

BOCAIUVA, Quintino. Estudos críticos e literários: lance d'olhos sobre a comédia e sua crítica. In: FARIA, João Roberto. Ideias teatrais. São Paulo: Perspectiva, 2001. p. 447-461.

CASTELlammaRE, Pietro de. Folhetim. Diário do Rio de Janeiro, Rio de Janeiro, 15 jul. 1869 , p. 1.

FARIA, João Roberto. Ideias teatrais. São Paulo: Perspectiva, 2001. . Machado leitor e crítico de teatro. Estudos Avançados, v. 18, n. 51, p. 299-333, 2004.

JORNAL DO COMMERCIO. Rio de Janeiro, 4 ago. 1845.

LA FAMA, Giornale di scienza, lettere, arti, industria e teatri. Milano, 24 mar. 1856.

LIMA SOBRINHO, Barbosa. Prefácio. In: ASSIS, Machado de. Adelaide Ristori: folhetins. Rio de Janeiro: Academia Brasileira de Letras, 1955.

MARTINS, Wilson. História da inteligência brasileira. São Paulo: Cultrix, 1978. v. II.

MELDOLESI, Claudio. Studio sulla poesia degli attori nell'Ottocento. Quaderni di Teatro, n. 21/22, 1983.

MINISTÉRIO DO IMPÉRIO. Relatório de 10 abr. 1852. Disponível em: $<$ http://memoria.bn.br>. Acesso em: 25 fev. 2019.

OLIVEIRA E CASTRO, L. J. Jornal do Comércio, 30 jun. 1869. In: ASSIS, Machado de CASTILHO, Antônio Feliciano de; MUZZIO, Henrique Cesar et al. Homenagem a Adelaide Ristori. Rio de Janeiro: Editores Dupont \& Mendonça, 1869. 
Machado de Assis em Linha — Universidade de São Paulo

http://machadodeassis.fflch.usp.br

P.A.L. Diário do Rio de Janeiro, 2 jul. 1869. In: ASSIS, Machado de CASTILHO, Antônio Feliciano de; MUZZIO, Henrique Cesar et al. Homenagem a Adelaide Ristori. Rio de Janeiro: Editores Dupont \& Mendonça, 1869a.

Jornal do Comércio. In: ASSIS, Machado de CASTILHO, Antônio Feliciano de; MUZZIO, Henrique Cesar et al. Homenagem a Adelaide Ristori. Rio de Janeiro: Editores Dupont \& Mendonça, 1869b.

RISTORI, Adelaide. Ricordi e studi artistici. Torino; Napoli: Roux, 1887.

SEMANA ILUSTRADA. 20 jun. 1869. In: ASSIS, Machado de CASTILHO, Antônio Feliciano de; MUZZIO, Henrique Cesar et al. Homenagem a Adelaide Ristori. Rio de Janeiro: Editores Dupont \& Mendonça, 1869.

TRAVASSOS, Renato. Cartas de Machado de Assis e Euclydes da Cunha. Rio de Janeiro: Waissman, Reis \& Cia., 1931.

VANNUCCI, Alessandra. Uma amizade revelada: correspondência entre Dom Pedro II e Adelaide Ristori, a maior atriz de seu tempo. Rio de Janeiro: Fundação Biblioteca Nacional, 2004.

VERSI DECLAMATI dall'insigne tragica a Pietro II Imperatore del Brasile, Rio de Janeiro, 3 jul. 1869. In: ASSIS, Machado de CASTILHO, Antônio Feliciano de; MUZZIO, Henrique Cesar et al. Homenagem a Adelaide Ristori. Rio de Janeiro: Editores Dupont \& Mendonça, 1869.

ALESSANDRA VANNUCCI é doutora em Letras pela PUC-Rio, professora de Direção Teatral na Escola de Comunicação da UFRJ, dramaturga e diretora premiada no Brasil e na Itália. Nos últimos quinze anos pesquisou ideias e artistas viajantes. Publicou Uma amizade revelada (2004); Crítica da razão teatral (2005); Un baritono ai tropici (2008); A missão italiana (2014) e diversos ensaios. Atualmente pesquisa expressões de arte e militância no espaço público da década de 1970 até hoje (Teatro do Oprimido, Living Theatre). E-mail: alevannucci@gmail.com

Recebido: 15.11 .2018

Aprovado: 12.01.2019 